\title{
Menciptakan Pimpinan Yang Handal Dalam Meningkatkan Kinerja Karyawan
}

\author{
JENITA \\ Akademi Keuangan dan Perbankan Riau (AKBAR) \\ Jln. HR. Subrantas 57 Panam Pekanbaru 28293 Telp. (0761) 63237 \\ E-mail : akbar_stier@yahoo.com
}

\begin{abstract}
The aim of this paper is to find out how to create reliable leaders in order to improve the employee performance in the organization that he leads. Reliable leaders are the foundation of effective leadership in which their thinking is a based on organization's task. The role of a leader is very significant to achieve the organization's task and goals and to improve employee performance, which are the effective and reliable leadership is able to provide guidance to any business activity in order to achieve organizational goals. The leadership style could be a proper guideline in improving employee performance of an organization. Improvement of an employee performance has a positive impact on the organization, and is expected to increase the effectiveness and efficiency of the organization. Either method is to create an effective leader and reliable
\end{abstract}

Keywords: Leaderhip, Performance

Pemimpin memegang peranan penting dalam kehidupan manusia, Sebagaimana hadis riwayat bukhari dan Muslim bahwa "Setiap kamu adalah pemimpin, dan setiap pemimpin akan dimintai pertanggungjawaban atas yang dipimpinnya", Pemimpin memberikan pengaruh yang sangat kuat dalam mencapai tujuan organisasi dan juga dapat memberikan motivasi kepada orang-orang yang dipimpinnya. Dalam mencapai visi dan misi suatu organisasi seorang pemimpin harus dapat menjalin kerja sama dengan para bawahan dan pihak -pihak eksternal.

Tanpa adanya dukungan dari orangorang disekitarnya baik internal maupun eksternal,seorang pimpinan tidak akan dapat mencapai tujuan organisasi.Sebagaimana pendapat Husein Umar (2008) bahwa ruang lingkup pembahasan perilaku keorganisasian diantaranya adalah tentang sikap dan perilaku, komunikasi, kepemimpinan relationship, pengendalian stress, kepuasaan kerja, motivasi, manajemen konflik.

Oleh karena itu, sebagai seorang pemimpin kita harus mampu mengorganisir diri-sendiri semaksimal mungkin, mulai dari manajemen waktu yang baik, mengontrol diri dalam berbicara, bersikap, dan berperilaku, serta dapat menjaga kesehatan dengan mengatur pola makan serta istirahat yang cukup.Jika telah mampu dan berhasil menjadi pemimpin yang baik untuk diri sendiri barulahdikembangkan potensi kepemimpinan dalam ranah yang lebih luas pada organisasi atau lembaga.Pemimpin merupakan orang yang akan mengatur, dan mengarahkan tujuan yang akan dicapai. Menjadi pemimpin tidak mudah.Lebih sulit lagi menjadi pemimpin yang baik.Sayangnya, banyak orang yang tidak menyadari bahwa mereka tidak layak menjadi seorang pemimpin.Ambisi yang besar sering menjadi modal satu-satunya (Faturochman, 1992).Faturochman berpendapat bahwa pola kepemimpinan tidak banyak berubah.Namun tuntutan masyarakat yang banyak berubah sejalan dengan perubahan zaman.Perkembangan ilmu pengetahuan punya andil besar dalam hal ini.Karena dengan berkembangnya ilmu pengetahuan dan teknologi menyebabkan masyarakat seakan mengikuti perubahan ini.Masyarakat merasa terpaksa untuk mengimbangi perubahan, terlebih dalam negara-negara berkembang dimana masih banyak kehidupan masyarakatnya jauh dari 
kesan modern yang dipenuhi dengan perangkat-perangkat teknologi canggih.Hal ini dapat kita temui dalam masyarakat Indonesia, yang berada di suku-suku pedalaman Sumatra, Jawa, Kalimantan dan Papua.

Indonesia memiliki beragam kebudayaan dengan sistem kepemimpinan yang berbeda-beda, tetapi tetap berpegang pada bhineka tunggal ika, sehingga Indonesia dapatberintegritas secara nasional dan menjadi suatu ikatan yang erat bagi seluruh bangsa Indonesia. Konflik yang terjadi disebabkan oleh karena pemimpin tidak memahami apa yang dipimpinnya. Dimana setiap pemimpin memiliki karakteristik yang berbeda-beda, maka seorang pemimpin harus dapat memahami tiga hal penting sesuai dengan apa yang disampaikan oleh Ivancevic et,al,(2006), bahwa tiga variable penting yang harus dihadapi setiap pemimpin adalah:1). Orang yang dipimpin.2). Tugas yang dijalankan orang-orang tersebut.3).lingkungan tempat orang dan tugas tersebut berada. Tiga variable ini berbeda dalam setiap situasi, sehingga apa yang diperlukan dan diharapkan dari seorang pemimpin juga berbeda pada setiap situasi.

Menjadi pemimpin bukan berarti otoritas atau berkuasa tetapi merupakan suatu amanah.Inti dari manajemen adalah kepemimpinan.Peran pemimpin atau kepemimpinan menjadi semakin penting dalam organisasi yang tumbuh semakin rumit dewasa ini seperti halnya dinamika dan pertumbuhan masyarakat yang juga semakin rumit. Sementara itu, kerumitan dinamikamasyarakat dewasa ini, baik di sektor bisnis maupun pemerintahan, maupun jugalembaga swadaya masyarakat, sering ditengarai sedang mengalami krisis global dan multidimensional yang terkait dengan krisis kepemimpinan di dalamnya (Wirawan, 2003)

Pemimpin adalah suatu faktor yang sangat penting bagi manajemen suatu organisasi. Pemimpin yang efektif mampu memotivasi anggota organisasinya agar produktifitas, loyalitas dan kepuasan anggota organisasi dapat meningkat. Dari waktu ke waktu kepemimpinan selalu mengalami pergeseran dan perubahan yang disebabkan oleh adanya perkembangan sosial, politik dan budaya yang berlaku.

$$
\text { Seringkali pengertian }
$$

kepemimpinan dan manajemen disamakan oleh banyak orang, namun ada pula yang membedakan pengertian keduanya.(Robbins, 2006) berpendapat bahwa kepemimpinan berbeda dari manajemen.Manajemen berkaitan dengan hal-hal untuk mengatasi kerumitan.Manajemen yang baik dapat menghasilkan tata tertib dan konsistensi dengan menyusun rencana-rencana formal.

Keberhasilan dalam pencapaian tujuan organisasi sangat tergantung dari peran pemimpin. Menurut Robbins (2003:62), Kepemimpinan Transformasional merupakan pemimpin yang memberikan pertimbangan dan rangsangan intelektual yang diindividualkan, dan yang memiliki karisma. Ketika pemimpin transformasional melaksanakan tugasnya, mereka mencoba menimbulkan kesadaran dari para pengikutnya dengan menyerukan cita-cita yang lebih tinggi dan nilai-nilai moral seperti kemerdekaan, keadilan, dan kemanusiaan, bukan berdasar atas emosi, seperti misalnya keserakahan, kecemburuan atau kebencian.

Para pengikut seorang pemimpin transformasional merasa adanya kepercayaan, kekaguman, kesetiaan, dan hormat terhadap pemimpin tersebut, dan mereka termotivasi untuk melakukan lebih daripada yang diharapkan pada mereka. Semakin pandai pemimpin transformasional tersebut melaksanakan peranannya, maka akan semakin cepat pula tujuan dari organisasi dapat tercapai, yaitu melalui peningkatan kinerja yang dapat dicapai karyawan.

Menurut Rivai (2005:2), dalam bukunya yang berjudul "Kepemimpinan Dan Perilaku Organisasi" menyatakan 
bahwa definisi kepemimpinan secara luas, adalah meliputi proses mempengaruhi dalam menentukan tujuan organisasi, memotivasi perilaku pengikut untuk mencapai tujuan, mempengaruhi interprestasi mengenai peristiwa-peristiwa para pengikutnya, pengorganisasian dan aktivitas-aktivitas untuk mencapai sasaran, memelihara hubungan kerja sama dan kerja kelompok, perolehan dukungan dan kerja sama dari orang-orang di luar kelompok atau organisasi.

Menurut Hasibuan (2003:170) "Kepemimpinan adalah cara seorang pemimpin mempengaruhi perilaku bawahan agar mau bekerja sama dan bekerja secara efektif dan efisien untuk mencapai tujuan organisasi". Selanjutnya menurut Istianto (2009:87) dalam bukunya Manajemen Pemerintahan, ada beberapa definisi kepemimpinan yang dapat mewakili tentang kepemimpinan, yaitu sebagai berikut :

1. Kepemimpinan adalah suatu kegiatan dalam memimpin sedangkan pemimpin adalah orangnya yang memiliki kemampuan untuk mempengaruhi orang lain sehingga orang lain tersebut mengikuti apa yang diinginkannya. Oleh karena itu pemimpin harus mampu mengatur dan mempengaruhi orang lain untuk mencapai tujuan bersama.

2. Kepemimpinan adalah dimana seorang pemimpin harus mampu mengatur dan mempengaruhi orang lain untuk mencapai tujuan bersama.

3. Kepemimpinan merupakan subjek yang penting di dalam manajemen dan ilmu administrasi karena kepemimpinan terkait dengan hubungan antara atasan dan bawahan di dalam organisasi.

4. Kepemimpinan merupakan proses berorientasi kepada manusia dan dapat diukur dari pengaruhnya terhadap perilaku organisasi.

5. Kepemimpinan pemerintahan adalah sikap, perilaku dan kegiatan pemimpin pemrintahan di pusat dan daerah dalam upaya mencapai tujuan penyelenggaraan pemerintahan negara.

Pengertian kepemimpinan menurut para ahli seperti M. S. P. Hasibuan (2007:170), kepemimpinan adalah :"Proses mempengaruhi orang lain untuk memahami dan setuju tentang apa yang akan dikerjakan dan bagaimana tugas itu dapat dilakukan secara efektif, dan proses memfasilitasi usaha individu dan kelompok untuk mencapai tujuan bersama".

Menurut Tzu dan Cleary (2002:5), berpendapat bahwa kepemimpinan adalah :"Sebuah persoalan kecerdasan, kelayakan untuk dipercaya, kelembutan, keberanian, dan ketegasan". Dan menurut Kounzes dan Posner (2004:3), kepemimpinan adalah :"Penciptaan cara bagi orang untuk berkontribusi dalam menciptakan sesuatu yang luar biasa". Sedangkan menurut pendapat Kartono (2005:153), kepemimpinan adalah :"Kemampuan untuk memberikan pengaruh yang konstruktif kepada orang lain untuk melakukan suatu usaha koperatif mencapai tujuan yang telah direncanakan".

Selain itu menurut Donni dan Suwatno (2011:140-141), kepemimpinan meliputi :

1. Penggunaan pengaruh dan bahwa semua hubungandapat melibatkan pimpinan.

2. Kepemimpinan mencakup pentingnya proses komunikasi, kejelasan dan keakuratan dari komunikasi mempengaruhi prilaku dan kinerja pengikutnya.

3. Kepemimpinan memfokuskan pada tujuan yang dicapai, pemimpin yang efektif harus berhubungan dengan tujuan-tujuan individu, kelompok dan organisasi.

Definisi kepemimpinan sangat bervariasi, sesuai dengan banyaknya para ahli yang mencoba mendefinisikan konsep kepemimpinan. Sebagaimana pendapat yang disampaikan oleh Yukl (2010:3) bahwa sebagian besar definisi 
kepemimpinan mencerminkan asumsi bahwa "kepemimpinan berkaitan dengan proses yang disengaja dari seseorang untuk menekankan pengaruhnya yang kuat terhadap orang lain untuk membimbing, membuat struktur, memfasilitasi aktivitas dan hubungan di dalam kelompok atau organisasi”.

Selanjutnya Engkoswara dan Aan (2011:177) menguraikan beberapa definisi kepemimpinan menurut para ahli, diantaranya: a. Rauch and Behling (1984:46), mengemukakan bahwa: "Kepemimpinan adalah proses mempengaruhi aktivitas-aktivitas sebuah kelompok yang diorganisasikan ke arah pencapaian tujuan". b. Kottler (1988), mengemukakan bahwa: "Kepemimpinan adalah proses menggerakkan seseorang atau sekelompok orang kepada tujuan-tujuan yang umumnya ditempuh dengan cara-cara yang tidak memaksa". c. Jacobs and Jacques (1990), mengemukakan bahwa: "Kepemimpinan adalah sebuah proses memberi arti (pengarahan berarti) terhadap usaha kolektif, dan yang mengakibatkan kesediaan untuk melakukan usaha yang diinginkan untuk mencapai sasaran". d. Dubrin, A.J. (2001:3), mengemukakan bahwa: "Kepemimpinan adalah kemampuan untuk menanamkan keyakinan dan memperoleh dukungan dari anggota organisasi untuk mencapai tujuan organisasi". e. Northouse, P.G. (2003:3), mengemukakan bahwa: "Kepemimpinan adalah suatu proses dimana individu mempengaruhi kelompok untuk mencapai tujuan umum". Selain pendapat para ahli diatas,

Siagian (2007:210), mengatakan bahwa :"Efektivitas kepemimpinan seseorang pada akhirnya dinilai dengan menggunakan kemampuan mengambil keputusan sebagai kriteria utamanya ".

Berdasarkan pendapat para ahli yang dikemukakan tersebut dapat dikatakan bahwa kepemimpinan merupakan suatu proses,karena melalui proses perilaku positifpemimpin dapat menggerakan, membimbing, mempengaruhi dan mengawasi bawahan untuk berfikir dan bertindak sehingga dapat memberikan kontribusi nyata dalam melaksanakan aktivitasnya untuk mencapai tujuan organisasi.Seorang pemimpin harus dapat memahami apa itu yang dikatakan pemimpin. Karena berdasarkan definisi pemimpin atau kepemimpinandiatas jelas terlihat bahwa pemimpin berusaha untuk dapat mempengaruhi atau mengarahkan bawahan atau anggotanya melalui suatu proses komunikasi yang baik agar tujuan organisasi dapat tercapai, dengan arti kata pemimpin harus dapat mempengaruhi, mendorong, mengarahkan, menggerakan dan memberdayakan semua sumber daya organisasi untuk mencapai tujuan organisasi.

\section{METODE}

Dalam melakukan pembahasan ini, penulis menggunakan dua methodologi yaitu : Kajian Kepustakaan. Kajian melalui ungkapan pendapat para pakar,tenaga ahli, para ekonom muslim yang ada kaitannya dengan topiK pembahasan ini. Di samaping itu data yang bersumber dari jurnal, makalah dan artikel lainnya juga dibutuhkan.

\section{PEMBAHASAN}

Teori kepemimpinan Menurut Kartono (2006), adalah penggeneralisasian satu seri perilaku pemimpin dan konsepkonsep kepemimpinannya, dengan menonjolkan latar belakang historis, sebabmusabab timbulnya kepemimpinan, persyaratan menjadi pemimpin, sifat-sifat utama pemimpin, tugas pokok dan fungsinya, serta etika profesi kepemimpinan. Sedangkan Menurut Rivai (2007), teori kepemimpinan dapat dibagi atas: 1.Teori sifat,artinya: teori yang berusaha untuk mengidentifikasikan karakteristik khas (fisik, mental, kepribadian) yang dikaitkan dengan keberhasilan kepemimpinan. Ada beberapa ciri-ciri unggul sebagai predisposisi yang diharapkan akan memiliki oleh seorang pemimpin, yaitu intelegensi tinggi, banyak inisiatif, energik, 
punya kedewasaan emosional, memiliki daya persuasif dan keterampilan komunikatif, memiliki kepercayaan diri, peka, kreatif, mau memberikan partisipasi sosial yang tinggi, dan lain-lain (Kartono, 2006). 2.Teori kepribadian pelaku,artinya:

Kepemimpinan jenis ini akan muncul berdasarkan kualitas-kualitas pribadi atau pola-pola kelakuan pemimpinnya. Teori ini menyatakan, bahwa seorang pemimpin itu selalu berkelakuan kurang lebih sama, yaitu ia tidak melakukan tindakan-tindakan yang identik sama dalam setiap situasi yang dihadapi (Kartono, 2006).3. Teori kepemimpinan situasional, yaitu: Suatu pendekatan terhadap kepemimpinan yang menyatakan bahwa pemimpin memahami perilakunya, sifat-sifat bawahannya, dan situasi sebelum menggunakan suatu gaya kepemimpinan tertentu. Dan pendapat lain tentang teori kepemimpinan adalah menurut Robbins (2003) bahwa: teori kepemimpinan neokharismatik. Yang terbagi atas tiga kelompok.Yaitu: Pertama, menekankan perilaku pemimpin yang simbolik dan menarik secara emosional, Kedua, berupaya menjelaskan bagaimana para pemimpin menghasilkan komitmen bagi para bawahnnya. Ketiga, memandang kepemimpinan sebagai subjek.

Fungsi pimpinan sangat penting bagi suatu organisasi dalam rangka mencapai tujuan dan sasaran organisasi yang dipimpinnya.Dimana fungsi kepemimpinan mempunyai kaitan yang erat dengan situasi sosial dalam berorganisasi, dimana fungsi kepemimpinan hendaknya dapatberinteraksi antara individu. Menurut Rivai (2005:53) secara operasional fungsi pokok kepemimpinan dapat dibedakan sebagai berikut :

1. Fungsi Instruktif Fungsi ini bersifat komunikasi satu arah. Pemimpin sebagai komunikator merupakan pihak yang menentukan apa, bagaimana, bilamana, dan dimana perintah itu dikerjakan agar keputusan dapat dilaksanakan secara efektif. Kepemimpinan yang efektif memerlukan kemampuan untuk menggerakkan dan memotivasi orang lainagar mau melaksanakan perintah.

2. Fungsi Konsultatif Fungsi ini bersifat komunikasi dua arah. Pada tahap pertama dalam usaha menetapkan keputusan, pemimpin kerapkali memerlukan bahan pertimbangan yang mengharuskannya berkonsultasi dengan orang-orang yang dipimpinnya yang dinilai mempunyai berbagai bahan informasi yang diperlukan dalam menetapkan keputusan. Tahap berikutnya konsultasi dari pimpinan pada orangorang yang dipimpin dapat dilakukan setelah keputusan ditetapkan dan sedang dalam pelaksanaan. Konsultasi itu dimaksudkan untuk memperoleh masukan berupa umpan balik (feedback) untuk memperbaiki dan menyempurnakan keputusankeputusan yang telah ditetapkan dan dilaksanakan. Dengan menjalankan fungsi konsultatif dapat diharapkan keputusan-keputusan pimpinan, akan mendapat dukungan dan lebih mudah menginstruksikannya sehingga kepemimpinan berlangsung efektif.

3. Fungsi Partisipasi Dalam menjalankan fungsi ini pemimpin berusaha mengaktifkan orang-orang yang dipimpinnya, baik dalam keikutsertaan mengambil keputusan maupun dalam melaksanakannya. Partisipasi tidak berarti bebas berbuat semaunya, tetapi dilakukan secara terkendali dan terarah berupa kerjasama dengan tidak mencampuri atau mengambil tugas pokok orang lain. Keikutsertaan pemimpin harus tetap dalam fungsi sebagai pemimpin dan bukan pelaksana.

4. Fungsi Delegasi Fungsi ini dilaksanakan dengan memberikan pelimpahan wewenang membuat atau menetapkan keputusan, baik melalui persetujuan maupun tanpa persetujuan dari pimpinan. Fungsi 
delegasi pada dasarnya berarti kepercayaan.Orang-orang penerima delegasi itu harus diyakini merupakan pembantu pemimpin yang memiliki kesamaan prinsip, persepsi dan aspirasi.

5. Fungsi Pengendalian Fungsi pengendalian bermaksud bahwa kepemimpinan yang sukses/ efektif mampu mengatur aktivitas anggotanya secara terarah dan dalam koordinasi yang efektif, sehingga memungkinkan tercapainya tujuan bersama secara maksimal. Fungsi pengendalian ini dapat diwujudkan melalui kegiatan bimbingan, pengarahan, koordinasi, dan pengawasan.

Pendapat tentang fungsi atau peranan dari pemimpin menunjukan nilai dan tujuan yang sama, walaupun ada perbedaan dari pendapat tersebut, namun memiliki tujuan yang sama dan saling melengkapi, hendaknya fungsi-fungsi tersebut diatas dapat dijadikan sebagai pedoman dalam membentuk kepribadian seorang pemimpin yang handal. Dengan kata lain para pemimpin memfokuskan diri pada pengarahan tindakan atau perilaku para bawahan mereka untuk tercapainya tujuan spesifik; para pemimpin tidak menaruh perhatian terhadap pengarahan tindakan atau perilaku yang tidak relevan dengan pencapaian tujuan organisasi atau kelompok. Namun pemimpin merupakan satu proses dua arah. Pemimpin sudah barang tentu mempengaruhi bawahan dengan berbagai cara, namun sebaliknya para pemimpin seringkali dipengaruhi pula oleh bawahan berarti seseorang tidak dapat memimpin kecuali ada pengikut.

Menurut Kreitner et al. (2003:441) ada tiga pendekatan teori kepemimpinan untuk memahami sifat-sifat pemimpin dan perilaku yang tepat pada berbagai situasi yaitu pendekatan sifat (traits approach), pendekatan perilaku (behavior approach) dan pendekatan situasional (situasional approach).

1) Pendekatan sifat (traits approach), Kajian teori kepemimpinan melalui pendekatan sifat yang dilakukan dengan cara mengidentifikasi ciri-ciri dan sifat kepribadian yang membedakan para pemimpin dengan pengikutnya, meliputi: (1) sifat-sifat kepribadian, yaitu: kemampuan adaptasi, kekuatan jasmani, agresivitas, ketegasan, daya imajinasi, kejujuran, keramahan, kemauan, ketenangan, kondisi emosional yang seimbang dan terkendali, kreativitas, integritas pribadi, dan percaya diri, (2) kemampuan pribadi yaitu: intelegensia, perrtimbangan dan keputusan, pengetahuan dan kemampuan berbicara, (3) kemampuan sosial yaitu: kemampuan dan kesiapan melakukan kerjasama, kemampuan adminstratif, popularitas, prestise, partisipasi sosial dan kebijaksanaan.

2) Pendekatan Perilaku (behavior approach). Pendekatan perilaku memandang bahwa keberhasilan seorang pemimpin ditentukan oleh perilaku kepemimpinan. Pendekatan ini dapat diidentifikasi dari perilaku kepemimpinan yang spesifik dari seorang pemimpin dalam kegiatannya untuk mempengaruhi anggota kelompok, misalnya cara memberi perintah, menegakkan disiplin, berkomunikasi, membuat keputusan dan cara menegur kesalahan bawahan. Perilaku kepemimpinan berfokus pada (1) perhatian terhadap tugas (2) perhatian terhadap orangorang yang melakukan tugas pekerjaan dan orientasi hubungan manusia.

3) Pendekatan Situasional (situational approach). Pendekatan ini berdasarkan atas kombinasi perilaku hubungan, perilaku tugas dan tingkat kedewasaan bawahan dalam peleksanaan fungsi, tugas dan sasaran.Pendekatan ini menekankan ketepatan perilaku kepemimpinan dengan kedewasaan bawahan. Faktor 
kunci kepemimpinan yang efektif adalah mengidentifikasi tingkat kedewasaan berfikir individu bawahan dan kelompok yang akan dipengaruhi untuk dijadikan dasar perilaku kepemimpinan yang sesuai.

Gaya kepemimpinan menurut Siagian (2003) menyatakan bahwa gaya kepemimpinan seseorang adalah identik dengan tipe kepemimpinan orang yang bersangkutan. Sedangkan menurut Wahjosumidjo (2002) bahwa perilaku pemimpin dalam proses pengambilan keputusan dan pemecahan masalah sesuai dengan gaya kepemimpinan seseorang. Gaya tersebut adalah sebagai berikut:

1. Gaya kepemimpinan Direktif adalah kemampuan mempengaruhi orang lain agar bersedia bekerja sama untuk mencapai tujuan yang telah ditentukan dengan cara segala kegiatan yang akan dilakukan diputuskan oleh pimpinan semata-mata.

2. Gaya kepemimpinan Konsultatif adalah kemampuan mempengaruhi orang lain agar bersedia bekerja sama untuk mencapai tujuan yang telah ditetapkan dengan cara berbagai kegiatan yang akan dilakukan oleh pemimpin setelah mendengarkan masukan/saran dari bawahan.

3. Gaya kepemimpinan Partisipatif adalah kemampuan mempengaruhi orang lain agar bersedia bekerja sama untuk mencapai tujuan yang telah ditetapkan dengan cara berbagai kegiatan yang akan dilakukan ditentukan bersama antara pimpinan dan bawahan.

4. Gaya kepemimpinan Delegatifadalah kemampuan mempengaruhi orang lain agar bersedia bekerja sama untuk mencapai tujuan yang telah ditetapkan dengan cara berbagai kegiatan yang akan dilakukan lebih banyak diserahkan kepada bawahan.

Gaya kepemimpinan seorang pemimpin mempunyai sifat, kebiasaan, tempramen, watak, dan kepribadian tersendiri yang unik dan khas, namun gaya dan tingkah laku yang membedakan dirinya dengan orang lain. Sejalan dengan itu Menurut G.R. Terry yang dikutip oleh Donni dan Swatno (20011:156-157), mengemukakan ada enam tipe kepemimpinan yaitu :

a. Kepemimpinan Pribadi (Personal Leadership)Dalam tipe ini pimpinan mengadakan hubungan langsung dengan bawahannya,sehingga timbul pribadi yang intim.

b. Kepemimpinan Non-Pribadi (NonPersonal Leadership)Dalam tipe ini pimpinan tidak mengadakan hubungan langsung dengan bawahannya, sehingga antara atasan dan bawahan tidak timbul kontak pribadi.

c. Kepemimpinan Otoriter (Authoriterian leadership)Dalam tipe ini pimpinan memperlakukan bawahannya sewenang-menang, karena menganggap diri orang yang paling berkuasa, bawahannya digerakan dengan jalan paksa, sehingga para pekerja dalam melakukan pekerjaannya bukan karena ikhlas melainkan karena takut.

d. Kepemimpinan Kebapakan (Paternal Leadership)Dalam tipe ini pemimpinan memperlakukan bawahannya seperti anak sendiri, sehingga para bawahannya tidak berani mengambil keputusan, segala sesuatu yang pelik diserahkan kepada bapak pimpinan untuk menyelesaikannya.

e. Kepemimpinan Demokratis (Democratic Leadership) Dalam tipe ini pimpinan selalu mengadakan musyawarah dengan para bawahannya untuk menyelesaikan pekerjaan-pekerjaan yang sukar.

f. Kepemimpian Bakat (Indigenous Leadership)Dalam tipe ini pimpinan dapat menggerakan bawahannya karena mempunyai bakat untuk itu, sehingga bawahannya senang 
mengikutinya. Tipe ini lahir karena bawaan sejak lahir.

Pendapat lain dari Donni dan Suwatno (2011:157-158), kepemimpinan dibagi menjadi empat jenis kepemimpinan yaitu :

1. Kepemimpinan Transaksional, Kepemimpinn ini berfokus pada transaksi antar pribadi, antara manajemen dan karyawan, dua karakteristik yamg melandasi kepemimpinan transaksional yaitu :

a. Para pemimpin menggunakan penghargaan kontigensi untuk motifasi para karyawan.

b. Para pemimpin melaksanakan tindakan korektif hanya ketika para bawahan gagal mencapai tujuan kinerja.

2. Kepemimpinan Kharismatik, Kepemimpinan ini menekankan prilaku pemimpin yang simbolis, pesan-pesan mengenai visi dan memberikan inspirasi, komunikasi non verbal, daya tarik terhadp nilai-nilai ideologis, stimulasi intelektual terhadap para pengikut oleh pimpinan, penampilan kepercayaan diri sendiri dan untuk kinerja yang melampaui panggilan tugas.

3. Kepemimpinan Visioner, Kepemimpinan ini merupakan kemampuan untuk menciptakan dan mengartikulasikan suatu visi yang realitas, dapat dipercaya, atraktif dengan masa depan suatu organisasi atau unit organisasi yang terus tumbuh dan mengikat.

4. Kepemimpinan Tim, Menjadi pemimpin efektif harus mempelajari ketrrampilan seperti kesabaran untuk membagi informasi, percaya pada orang lain, menghentikan otoritas dan memahami kapan harus melakukan intervensi.

Menurut Haryono Sudriamunawar

(2006) ada 3 kepemimpinan yaitu :

1. Gaya Otokratis, gaya kepemimpinan otokratis dapat pula disebut "tukang cerita" pemimpin otokratis biasanya merasa bahwa mereka mengetahui apa yang mereka inginkan dan cenderung mengekspresikan kebutuhan-kebutuhan tersebut dalam bentuk perintah-perintah langsung pada bawahan.

2. Gaya Partisipatif, gaya kepemimpinan partisipatif dikenal pula dengan istilah gaya demokratis, gaya ini berasumsi bahwa para anggota organisasi yang ambil bagian secara pribadi dalam proses pengambilan keputusan akan lebih memungkinkan sebagai suatu akibat mempunyai komitmen yang jauh lebih besar pada sasaran dan tujuan organisasi, bukan tidak berarti memungkinkan sebagai suatu akibat mempunyai komitmen yang jauh lebih besar pada sasaran dan tujuan organisasi, bukan tidak berarti para pemimpin tidak membuat keputusan tapi justru para pemimpin seharusnya memahami terlebih dahulu apakah yang menjadi sasaran organisasi sehingga mereka dapat menggunakan pengetahuan para anggotanya.

3. Gaya kendali bebas, istilah lain dari gaya ini yaitu "laissez faire" pendepatan ini tidak berarti tidak ada sama sekali pimpinan, ini hanya berarti tidak adanya pimpinan langsung. Menurut pendekatan ini suatu tugas disajikan kepada kelompok yang biasanya menentukan teknik-teknik mereka sendiri guna mencapai tujuan tersebut dalam rangka mencapai sasaran-sasaran kebijaksanaan organisasi. Pada dasarnya seorang pemimpin bertindak sebagai seorang penghubung antara sumber luar dan kelompok serta menegaskan bahwa tersedia sumber daya yang diperlukan bagi kepentingan anggota.

Sedangkan Menurut House Robbins yang dikutip oleh Donni dan Suwatno (2011:158), gaya kepemimpinan dapat dibagi menjadi empat yaitu : 
a. Kepemimpinan

Direktif,

Kepemimpinan ini membuat bawahan agar tahu apa yang diharapkan pimpinan dari mereka, menjadwalkan kerja untuk dilakikan, dan memberi bimbingan khusus mengenai bagemana menyelesaikan tugas.

b. Kepemimpinan yang Mendukung, Kepemimpinan ini bersifat ramah dan menunjukkan kepedulian akan kebutuhan bawahan.

c. Kepemimpinan Partisipatif, Kepemimpinan ini berkonsultasi dengan bawahan dan menggunakan saran mereka sebelum mengambil keputusan.

d. Kepemimpnan Berorientasi pada Prestasi, Kepemimpinan ini menetapkan tujuan yang menantang dan mengharapkan bawahan untuk berprestasi pada tingkat tertinggi mereka.

Sementara gaya kepemimpinan

Menurut Yusuf Suit, Almasdi (2000), adalah sebagai berikut :

1. Demokrasi, setiap orang dapat memberikan pokok-pokok pikiran melalui saluran tertentu. Kelemahannya adalah segala sesuatu yang hendak dicapai berjalan lamban dan tidak jarang menemui kesulitan dalam menyatukan pokok-pokok pikiran, sehingga tidak mustahil pula ada yang hendak dituju itu menjadi tertunda-tunda atau menjadi terbengkalai. Tetapi, jika dapat berjalan dengan ketentuan-ketentuan yang telah digariskan bersama, hasilnya akan baik.

2. Dikrator atau otoriter, orang yang dapat menghemat waktu, tetapi banyak sekali pokok-pokok pikiran yang tertampung dan bahkan tidak mustahil pula ditemui kegagalankegagalan, karena segala sesuatunya berjalan menurut selera penguasa tertinggi yang kadang-kadang tidak terkendali dengan baik.

3. Konsultatif, kebiasaan yang dilakukan seorang pemimpin sebelum mengambil keputusan adalah memanggil staf atau bawahan tertentu, untuk berkonsultasi meminta pandangan atau pikiran.

Adapun gaya kepemimpinan menurut Edy Sutisna (222-224) terdapat 10 gaya kepemimpinan yaitu :

1. Gaya Persuasif, yaitu gaya memimpin dengan menggunakan pendekatan yang menggugah perasaan, pikiran, atau dengan kata lain dengan melakukan ajakan atau bujukan.

2. Gaya refrensif,yaitu gaya kepempinan dengan cara memberikan tekanantekanan, ancaman-ancaman, sehingga bawahan merasa ketakutan.

3. Gaya partisipatif, yaitu gaya Kepemimpinan dimana memberikan kesempatan pada bawahan untuk ikut secara aktif baik mental, sepiritual, fisik, maupun materiil dalam kiprahnya di organisasi.

4. Gaya inovatif, yaitu pemimpin yang selalu berusaha dengan keras untuk mewujudkan usaha-usaha pembaruan disegala bidang, baik bidang politik, ekonomi, sosial, budaya, atau setiap produk terkait dengan kebutuhan manusia.

5. Gaya investigatif, yaitu gaya pemimpin yang selalu melakukan penelitian yang disertai dengan rasa penuh kecurigaan terhadap bawahannya sehingga menimbulkan yang menyebabkan kreativitas, inovasi, serta inisiatif dari bawahan kurang berkembang, karena bawahan takut melakukan kesalahan.

6. Gaya inspektif, yaitupemimpin yang suka melakukan acara-acara yang sifatnya protokorer, kepemimpinan ini menuntut penghormatan bawahan, atau pemimpin yang senang dihormati.

7. Gaya motivatif, yaitu pemimpin yang dapat menyampekan informasi mengenai ide-idenya, prograprogram, dan kebijakan-kebijakan 
kepada bawahan dengan baik. Komunikasi tersebut membuat segala ide, program, dan kebijakan yang dapat dipahami oleh bawahan sehingga bawahan mau merealisasikan semua ide, program, dan kebijakn yang ditetapkan oleh pimpinan.

8. Gaya naratif, yaitu yang bergaya naratif merupakan pimpinan yan banyak bicara namun tidak disesuaikan dengan apa yang ia kerjakan, atau dengan kata lain pimpinan yang banyak bicara tapi sedikit bekerja.

9. Gaya edukatif, yaitu pimpinan yang suka melakukan pengembangan bawahan dengan dengan cara memberikan pendidikan dan ketrampilan kepada bawahan, sehingga bawahan memiliki wawasan dan pengalaman yang lebih baik dari hari kehari. Sehingga pemimpin yang bergaya edukatif takkan pernah menghalangi bawahannya yang ingin mengembangkan pengetahuan dan ketrampilan.

10. Gaya retrogresif, yaitu pimpinan tidak suka melihat maju, apalagi melebihi dirinya.Untuk itu pemimpin yang bergaya retrogresif selalu menghalangi bawahannya untuk mengembangkan pengetahuan dan ketrampilan, sehingga dengan kata lain pemimpin yang bergaya ini sangat senang dengan bawahannya selalu terbelakang, bodoh, dan sebagainnya.

Selanjutnya Ishak Arep dan Tanjung (2003:23) menyatakan bahwa dalam mencapai tujuan sebagaimana telah dikemukakan diatas, yakni untuk dapat menguasai atau mempengaruhi serta memotivasi orang lain, maka dalam penerapan Manajemen Sumber Daya Manusia lazimnya digunakan 4 (empat) macam gaya kepemimpinan, yaitu :

1. Democratic Leadership adalah suatau gaya kepemimpinan yang menitikberatkan kepada kemampuan untuk menciptakan moral dan kemampuan untuk menciptakan kepercayaan

2. Dictatorial atau Autocratic Leadership, yakni suatu gaya leadership yang menityikberatkan kepada kesanggupan untuk memaksakan keinginannya yang mampu mengumpulkan pengikutpengikutnya untuk kepentingan pribadinya dan/atau golongannya dengan kesediaan untuk menerima segala resiko apapun.

3. Paternalistic Leadership, yakni bentuk antara gaya pertama (democratic) dan kedua (dictatorial) diatas. Yang pada dasarnya kehendak pemimpin juga harus berlaku, namun dengan jalan atau melalui unsur-unsur demokratis. Sistem dapat diibaratkan diktator yang berselimutkan demokratis.

4. Free Rein Leadership, yakni salah satu gaya kepemimpinan yang $100 \%$ menyerahkan sepenuhnya seluruh kebijakan pengoperasian Manajemen Sumber Daya Manusia kepada bawahannya dengan hanya berpegang kepeda ketentuan-ketentuan pokok yang ditetapkan oleh atasan mereka. Pimpinan disini hanya sekedar mengawasi dari atas dan menerima laporan kebijaksanaan pengoperasian yang telah dilaksanakan oleh bawahannya. Gaya kepemimpinan ini terutama diterapkan oleh Pemerintah Republik Indonesia.

Berbagai macam gaya kepemimpinan yang dikemukakan oleh beberapa para ahli dapat digunakan dan dipilih mana yang lebih tepat dan dapat membentuk atau menjadikan seorang pemimpin yang dikatakan handal. Bahkan dari gaya kepemimpinan diatas juga dapat dikolaborasikan antara satu dengan yang lainnya, dengan memperhatikan sisi positifnya, yang dapat membawa kebaikan bagi keduabelah pihak, antara atasan dengan bawahan.Gaya kepemimpinan yang tepat yang didasarkan pada pemimpin, pengikut dan situasi. Jadi, gaya kepemimpinan yang 
paling sesuai tergantung pada situasi di mana pemimpin bekerja. yang memfokuskan pada faktor-faktor situasional, sifat pekerjaan, lingkungan eksternal dan karakteristik para pengikut.Kinerja dapat ditingkatkan bila hubungan pemimpin dan pengikut, struktur tugas, dan posisi kewenangan cocok dengan gaya kepemimpinan

Pemimpin yang diharapkan adalah seorang pemimpin yang handal, artinya pemimpin yang tangguh dan terampil dan mempunyai karisma, serta dapat memahami lingkungan dimana dia memimpin. Berdasarkan Survei yang dilakukan majalah SWA (Majalah SWA, Januari 2001) dalam mencari Chief Executive Officer (CEO) terbaik tahun 2000 di Indonesia, tampak bahwa karakteristik kepemimpinan yang terbukti menjamin eksistensi organisasi antara lain adalah perhatian terhadap bawahan.Karakteristik ini menempati peringkat kedua terpenting setelah visi sang pemimpin. Ini berarti bahwa pengelolaan manusia dalam organisasi merupakan kunci untuk memperbaiki kinerja organisasi dan kesiapan menghadapi perubahan di abad 21 (Alimuddin, 2002).

Pengertian tunggal tentang kepemimpinan masih belum ada kesepakatan diantara para ahli ilmu perilaku.Konsep kepemimpinan masih merupakan sesuatu yang ambigous Pfeffer dalam Payamta (2002). Sedangkan Luthans (1995), menyatakan bahwa definisi kepemimpinan masih merupakan "black box" atau "unexplainable concept".Setiap pemimpin sekurang-kurangnya memiliki tiga syarat Burton (2002), yakni :

1. Memiliki Persepsi Sosial (Social Perception), Persepsi sosial ialah kecakapan untuk cepat melihat dan memahami perasaan, sikap, dan kebutuhan anggota kelompok.

2. Kemampuan Berpikir Abstrak (Ability in Abstract Thinking), Kemampuan berabstraksi dibutuhkan oleh seorang pemimpin untuk dapat menafsirkan kecenderungan-kecenderungan kegiatan, baik di dalam maupun di luar kelompok, dalam kaitannya dengan tujuan kelompok. Kemampuan tersebut memerlukan taraf intelegensia yang tinggi pada seorang pemimpin.

3. Keseimbangan Emosional (Emotional Stability), Pada diri seorang pemimpin harus terdapat kematangan emosional yang berdasarkan kesadaran yang mendalam akan kebutuhan, keinginan, cita-cita dan suasana hati, serta pengintegrasian kesemua hal tersebut ke dalam suatu kepribadian yang harmonis sehingga seorang pemimpin dapat turut merasakan keinginan dan cita-cita anggota kelompoknya.

Sejalan dengan itu Yukl et al. (2002:15-32) menyebutkan empat taksonomi integrasi perilaku kepemimpinan yang efektif adalah:

1. Kemampuan Membangun Hubungan, Yaitu sikap/perilaku mendukung, mengembangkan, membimbing bawahan, membangun tim kerja, mengelola konflik, dan membentuk jaringan.

2. Kemampuan Mencari dan Memberikan Informas.Yaitu aktifitas memonitoring, menjelaskan dan menginformasikan ke bawahan.

3. Kemampuan Membuat Keputusan, Yaitu dalam hal merencanakan, memecahkan masalah, berkonsultasi dan pendelegasian.Kemampuan Mempengaruhi Orang Lain, Yaitu dalam hal memotivasi, mengakui, dan memberikan imbalan kepada bawahan.

Keutamaan seorang pemimpin adalah suatu proses yang dapat mempengaruhi, artinya satu proses dimana seorang pemimpin merubah tindakan atau perilaku beberapa anggota kelompok atau bawahan.Secara umum pemimpin berkaitan dengan penggunaan teknik mempengaruhi yang tidak memaksa.Dengan kata lain bawahan menerima pengaruh dari pemimpin karena mereka menghormati, menyukai, atau menghargai pemimpinnya, bukan hanya 
karena para pemimpin tersebut memegang jabatan dari kekuasaan secara formal.Salah satu tugas utama dari seorang pemimpin adalah membuat keputusan.

Karena keputusan2 yg diambilpara pemimpin sering kali berdampak pada bawahannya, maka jelas bahwa komponen utama dari efektifitas pemimpin adalah kemampuan mengambil keputusan yang sangat menentukan keberhasilan pemimpindalam melaksanakan tugas-tugas penting. Dimana Pemimpin yang mampu membuat keputusan dengan baik akan lebih efektif dalam jangka panjang dibanding dengan mereka yg tidak mampu membuat keputusan dengan baik dan tepat.

Ciri-ciri utama seorang pemimpin menurut Davis dalam Reksohadiprodjo dan handoko (2003:290) adalah: 1. Kecerdasan ( Intelligence), 2. Kedewasaan, social dan hubungan social yang luas ( Social maturity and Breadht), 3. Motivasi diri dan dorongan berprestasi, 4.Sikap-sikap hubungan manusiawi.Sedangkan indikator lain menurut Siagian $(2002 ; 121)$ adalah: 1. Iklim saling mempercayai,2. Penghargaan terhadap ide bawahan, 3.Memperhitungkan perasaan para bawahan, 4.Perhatian pada kenyamanan kerja bagi para bawahan. 5. Perhatian pada kesejahteraan bawahan, 6. Memperhitungkan factor kepuasan kerja para bawahan dalam menyelesaikan tugas-tugas yang dipercayakan padanya. 7. Pengakuan atas status para bawahan secara tepat dan professional.

Sondang P. Siagian yang dikutip oleh Sihotang (2007:258), menyebutkan cirri-ciri dan syarat-syarat kepemimpinan adalah sebagai berikut :

1. Pendidikan umum yang luas,Memiliki pengetahuan yang luas baik yang didapat secara formal maupun nonformal.

2. Kemampuan analisis,Pimpinan mampu menganalisa dalam menetukan langkah-langkah dalam pencapaian tujuan.

3. Keterampilan berkomunikasi,Memilki kemampuan berkomunikasi yang baik dalam penyampaian perintah kepada para karyawan.

4. Rasionalitas dan objektivitas,Pimpinan dalam menentukan tujuan haruslah bersifat rasional dan dalam menilai para bawahannya hendaknya bersifat objektif.

5. Programatis,Pimpinan dalam menyusun langkah-langkah dalam proses pencapaian tujuan harus terprogram, tersusun dan terkonsep.

6. Kesederhanaan,Pimpinan hendaknya mampu memberikan contoh dengan kesederhanaan terhadap para karyawan agar tidak terlalu royal.

7. Keberaniaan mengambil keputusan,Dalam pelaksanaan pengambilan keputusan pimpinan berani mengambil resiko.

8. Kemampuan mendengar saransaran,Pimpinan yang demokratis harus mau mendengarkan bawahannya agar terhindar dari sifat otoriter.

9. Adaptabilitas dan fleksibilitas,Seorang pemimpin harus bisa beradapatasi dengan lingkungannya agar mampu menciptakan lingkungan kerja yang kondusif.

10. Ketegasan dalam bertindak,Seorang pemimpin dalam pengambilan keputusan harus bersikap tegas tanpa kompromi agar disegani oleh para bawahannya.

Selanjutnya konsep kinerja merupakan salah satu factor penting dalam Manajemen sumber daya manusia, kinerja menurutMenurut Amstrong dan Baron dalam Sedarmayanti (2011:202) mengatakan "kinerja merupakan sarana untuk mendapatkan hasil lebih baik dari organisasi, tim, dan individu dengan cara memahami dan mengelola kinerja dalam kerangka tujuan dan standar, dan persyaratan atribut yang disepakati. Sedangkan menurut Anwar Prabu (2003:355) yang dikutip dari (http://intanghina.wordpress.com/2008/06/10 /kinerja/) bahwa kinerja merupakan perilaku 
nyata yang ditampilkan setiap orang sebagai prestasi kerja yang dihasilkan oleh karyawan sesuai dengan perannya dalam perusahaan.Selanjutnya Rivai (2005:309) mengatakan bahwa kinerja merupakan perilaku nyata yang ditampilkan setiap orang sebagai prestasi kerja yang dihasilkan oleh karyawan sesuai dengan perannya dalam perusahaan.

Pengertian kinerja juga dikemukakan oleh beberapa ahli manajemen dalam (Tika, 2006:121) antara lain sebagai berikut: 1 . Prawiro Suntoro mengemukakan bahwa kinerja adalah hasil kerja yang dicapai seseorang atau sekelompok orang dalam suatu organisasi dalam rangka mencapai tujuan organisasi dalam periode tertentu. 2. Handoko mendefinisikan kinerja sebagai proses dimana organisasi mengevaluasi atau menilai prestasi kerja karyawan.sedangkan menurut Sedarmayati (2011:259) "kinerja merupakan pencapaian/prestasi seseorang berkenan dengan tugas yang diberikan kepadanya".

Sejalan dengan itu Bernardian dan Joyce dalam Sedarmayanti $(2011 ; 260)$ kinerja didefinisikan sebagai "catatan mengenai outcomeyang dihasilkan dari suatu aktifitas tertentu,selama kurun waktu tertentu pula". Dan menurut Hasibuan (2013:95-96) terdapat sebelas unsur yang dinilai darikinerja karyawan, yaitu: 1. Kesetiaan 2. Prestasi kerja3.Kejujuran 4.Kedisiplinan 5.Kreativitas 6.Kerjasama 7.Kepemimpinan 8.Kepribadian 9.Prakarsa 10.Kecakapan 11. Tanggung jawab

Berdasarkan definisi dari para ahli diatas, dapat disimpulkan bahwa kinerja seorang pegawai merupakan hasil kerja atau kegiatan seorang pegawai secara kualitas dan kuantitas dalam suatu organisasi untuk mencapai tujuan dalam melaksanakan tugas dan pekerjaan yang diberikan kepadanya.Kinerja juga merupakan penampilan individu maupun kelompok kerja.Tiga hal penting dalam kinerja adalah tujuan, ukuran, dan penilaian.Penentuan tujuan setiap unit organisasi merupakan strategi untuk meningkatkan kinerja. Tujuan kinerja akan memberikan arah dan mempengaruhi bagaimana seharusnya perilaku kerja yang diharapkan organisasi dari setiap karyawan. Tetapi ternyata tujuan saja tidak cukup, sebab itu diperlukan ukuran apakah seorang karyawan telah mencapai kinerja yang diharapkan. Untuk itu penilaian kuantitatif dan kualitatif standar kinerja untuk setiap tugas dan jabatan karyawan memegang peranan yang penting. Akhir dari proses kinerja adalah penilaian kinerja itu sendiri yang dikaitkan dengan proses pencapaian tujuan.

Kinerja menurut Boediharjo $(2002 ; 102)$ dapat diukur berdasarkan empat indicator yaitu: 1. Efektif dan efisien, 2. Otoritas dan tanggung jawab, 3. Disiplin, 4. Inisitif.Untuk mengukur kinerja organisasi dapat digunakan teori Balance Scorecard. Kaplan dan Norton dalam Mangkunegara (2009:43) mengemukakan bahwa Balance Scorecard digunakan untuk menciptakan suatu gabungan pengukuran strategis, pengukuran finansial dan nonfinansial serta pengukuran ekstern dan intern pengukuran perusahaan dan dipandang menjadi empat katagori prespektif, yaitu: prespektif finansial, prespektif langganan, prespektif internal bisnis, serta prespektif pembelajaran dan pertumbuhan. Keempat prespektif ini saling berhubungan dalam sebab akibat, sebagai cara untuk menerjemahkan strategi ke dalam tindakan.

Anoraga (2001:52) mengemukakan bahwa faktor-faktor yang dapat mempengaruhi kinerja seseorang/individu antara lain mencakup: daya tarik pekerjaan, upah (insentif), kemauan dan perlindungan kerja, pengetahuan, lingkungan dan suasana kerja, harapan pengembangan karer, keterlibatan dalam kegiatan organisasi, perhatian dan kepemimpinan atasan.

Menurut A.Dele Timple dalam Anwar Prabu Mangkunegara (2005:15) menyatakan bahwa faktor-faktor kinerja meliputi faktor internal dan faktor eksternal, sebagai berikut:

1. Faktor Internal,(dispositional) yaitu faktor-faktor yang dihubungkan dengan sifat-sifat seseorang, misalnya kinerja seseorang baik disebabkan karena 
mempunyai kemampuan tinggi dan seseorang itu mempunyai tipe pekerja keras, sedangkan seseorang mempunyai kinerja jelek disebabkan orang tersebut mempunyai kemampuan rendah dan orang tersebut tidak memiliki upayaupaya untuk memperbaiki kemampuannya.

2. Faktor Eksternalyaitu faktor-faktor yang mempengaruhi kinerja seseorang yang berasal dari lingkungan seperti perilaku, sikap dan tindakan-tindakan rekan kerja, bawahan dan pimpinan, fasilitas kerja dan iklim organisasi.Faktor internal dan faktor eksternal ini merupakan jenis-jenis atribut yang mempengaruhi kinerja seseorang.

Ukuran-ukuran kinerja pegawai, Ranupandojo dan Husnan (2000) menjelaskan secara rinci sejumlah aspek yang meliputi:

1. Kualitas kerja adalah mutu hasil kerja yang didasarkan pada standar yang ditetapkan. Kualitas kerja diukur dengan indikator ketepatan, ketelitian, keterampilan dan keberhasilan kerja.Kualitas kerja meliputi ketepatan, ketelitian, kerapihan dan kebersihan hasil pekerjaan.

2. Kuantitas kerja yaitu banyaknya hasil kerja sesuai dengan waktu kerja yang ada, yang perlu diperhatikan bukan hasil rutin tetapi seberapa cepat pekerjaan dapat terselesaikan.Kuantitas kerja meliputi output, serta perlu diperhatikan pula tidak hanya output yang rutin saja, tetapi juga seberapa cepat dia dapat menyelesaikan pekerjaan yang ekstra.

3. Dapat tidaknya diandalkan termasuk dalam hal ini yaitu mengikuti instruksi, inisiatif, rajin, serta sikap hati-hati.

4. Sikap, yaitu sikap terhadap pegawai perusahaan dan pekerjaan serta kerjasama.

Amstrong dalam Sidik Priadana (2008:1) menyatakan pengelolaan kinerja merupakan proses yang dikendalikan oleh manajer lini dengan tujuan meningkatkan kinerja organisasi, team work dan individu. Dalam pengelolaan kinerja, manajer bekerjasama dengan karyawan untuk menetapkan tujuan penelitian, mengarahkan kinerja, memberi feedback, mengevaluasi kinerja dan memberi penghargaan kepada karyawan.Realisasi aktivitas tersebut mendukung keberhasilan perusahaan pada masa mendatang.

Menurut A.Dele Timple dalam Anwar Prabu Mangkunegara (2005:15) menyatakan bahwa faktor-faktor kinerja meliputi faktor internal dan faktor eksternal, sebagai berikut:

1. Faktor Internal,(dispositional) yaitu faktor-faktor yang dihubungkan dengan sifat-sifat seseorang, misalnya kinerja seseorang baik disebabkan karena mempunyai kemampuan tinggi dan seseorang itu mempunyai tipe pekerja keras, sedangkan seseorang mempunyai kinerja jelek disebabkan orang tersebut mempunyai kemampuan rendah dan orang tersebut tidak memiliki upayaupaya untuk memperbaiki kemampuannya.

2. Faktor Eksternal, yaitu faktor-faktor yang mempengaruhi kinerja seseorang yang berasal dari lingkungan seperti perilaku, sikap dan tindakan-tindakan rekan kerja, bawahan dan pimpinan, fasilitas kerja dan iklim organisasi. Faktor internal dan faktor eksternal ini merupakan jenis-jenis atribut yang mempengaruhi kinerja seseorang.

Pendapat lain dari Suwatno (2001:161), mengatakan bahwa faktor-faktor yang mempengaruhi kepemimpinan adalah sebagai berikut :

1. Faktor genetis Adalah faktor yang menampilkan pandangan bahwa seseorang menjadi pemimpin karena latar belakang keturunannya.

2. Faktor social, Faktor ini pada hakikatnya semua orang sama dan bisa menjadi pemimpin. Setiap orang memiliki kemungkinan untuk menjadi seorang pemimpin, dan tersalur sesuai lingkungannya.

3. Faktor bakat,Faktor yang berpandangan bahwa seseorang hanya 
akan berhasil menjadi seorang pemimpin yang baik, apabila orang itu memang dari sejak kecil sudah membawa bakat kepemimpinan.

Berdasarkan faktor-faktor yang mempengaruhi kepemimpinan diatas, maka jelas terlihat bahwa kesuksesan seorang pemimpin dalam beraktivitas sangat dipengaruhi oleh faktor keberhasilan seorang pemimpin. Tujuan suatu organisasi akan dapat dicapai apabila adanya hubungan atau interaksi yang harmonis antara pimpinan dengan bawahan. Disamping factor-faktor yang mempengaruhi kesuksesan seorang pemimpin tersebut yang paling utama adalah latar belakangyang dimiliki oleh seorang pemimpin yaitu motivasi pemimpin itu sendiri, atau karismatiknya.

Dalam teori jalur tujuan (Path Goal Theory) yang dikembangkan oleh Robert House (dalam Kinicki, 2005) menyatakan bahwa pemimpin mendorong kinerja yang lebih tinggi dengan cara memberikan kegiatan-kegiatan yang mempengaruhi bawahannya agar percaya bahwa hasil yang berharga bisa dicapai dengan usaha yang serius. Kepemimpinan yang berlaku secara universal menghasilkan tingkat kinerja dan kepuasan bawahan yang tinggi. Dalam situasi yang berbeda mensyaratkan gaya kepemimpinan yaitu karakteristik personal dan kekuatan lingkungan.

Teori ini juga menggambarkan bagaimana persepsi harapan dipengaruhi oleh hubungan kontijensi diantara empat gaya kepemimpinan dan berbagai sikap dan perilaku karyawan. Perilaku pemimpin memberikan motivasi sampai tingkat: (1) Mengurangi halangan jalan yang mengganggu pencapaian tujuan.(2) Memberikan panduan dan dukungan yang dibutuhkan oleh para karyawan.(3) Mengaitkan penghargaan yang berarti terhadap pencapaian tujuan.Menurut Kerlinger dan Padhazur (2002) faktor kepemimpinan mempunyai peran yang sangat penting dalam meningkatkan kinerja pegawai karena kepemimpinan yang efektif memberikan pengarahan terhadap usahausaha semua pekerja dalam mencapai tujuan- tujuan organisasi.Gaya kepemimpinan yang efektif dibutuhkan pemimpin untuk dapat meningkatkan kinerja semua pegawai dalam mencapai tujuan organisasi sebagai instansi pelayanan publik. Dengan demikian, gaya kepemimpinan dapat menjadi pedoman yang baik dalam peningkatan kinerja pegawai .

Setiap pemimpin mempunyai kewenangan dan tanggung jawab dalam menentukan seluruh kegiatan diperusahaan, hal ini sejalan dengan pendapat BA. Soetisno (2002), setiap manajer atau pimpinan organisasi tertentu memiliki tanggung jawab yang besar dalam seluruh proses yang biasanya termasuk dalam manajemen sumber daya manusia yang berkaitan dengan para pegawai yang berada dalam kewenangannya, sehingga dibutuhkan kemampuan dan keterampilan yang tinggi untuk memimpin karyawannya dalam perusahaan.

Hal tersebut diperkuat oleh AM. Kadarman, Jusuf Udaya, dkk (2001), yang berpendapat bahwa tugas seorang pemimpin adalah mendorong bawahannya untuk mencapai tujuan. Jadi dalam memimpin pasti terlibat kemampuan seseorang untuk mempengaruhi atau memotivasi orang lain atau bawahannya agar mereka mau melaksanakan tugas yang diberikan kepadanya dengan baik. Dalam konteks ini, motivasi menjelaskan suatu aktifitas manajemen atau sesuatu yang dilakukan seorang manajer untuk membujuk atau mempengaruhi bawahannya untuk bertindak secara organisatoris dengan cara tertentu agar dapat menghasilkan kinerja yang efektif.

Dari pendapat-pendapat diatas dapat dikatakan bahwa seorang pemimpin bertugas untuk mempengaruhi dan memotivasi karyawannya dengan cara menggunakan gaya kepemimpinan yang tepat agar karyawan mau melaksanakan tugas yang diberikan kepadanya dengan baik dan menghasilkan tenaga yang efektif.Pada kenyataannya bahwa para pemimpin sering kali memiliki hubungan yang berbeda dengan bawahannya.Hubungan ini selanjutnya sangat mempengaruhi kepuasan, kinerja dan persepsi bawahan terhadap 
pemimpinnya.Kualitas hubungan para manajer muda dengan para supervisornya telah terbukti mempengaruhi perjalanan karir mereka.

\section{SIMPULAN}

Seorang pemimpin harus dapat melakukan perubahan karakter yang berasal dari dalam diri sendiri kearah yang lebih baik, dan memiliki visi dan misi yang jelas untuk tujuan yang ingin dicapai suatu organisasi, serta memiliki kompetensi yang tinggi dari seorang pemimpin.Dan yang tak kalah pentingnya, seorang pemimpin harus punya jati diri.Pemimpin yang diharapkan sebagai pemimpin yang handal adalah pemimpin yang berdasarkan pada kepemimpinan strategis artinya kepemimpinan yang bertanggung jawab untuk menciptakan harmoni antara tuntutan lingkungan ekstrenal organisasi (dunia) dengan visi, misi, strategi dan implementasi organisasi.Pemimpin yang handal harus memiliki gaya kepemimpinan yang sesuai dengan situasi bawahan, dan situasi lingkungan.

Strategi disini merupakan niat (intention), implementasi melalui struktur, sistem, budaya dan iklim, sistem insentif, menjamin terwujudnya visi di masadepan, yang bertujuan menyediakan arah yang dapat menterjemahkan visi menjadi aksi dan merupakan dasar bagi pengembangan mekanisme spesifik untuk menolong organisasi mencapai tujuannya.

Pemimpin yang handal harus punya kemampuan untuk melihat masa depan, mampu memprediksi perubahan yang akan terjadi, mampu melihat hambatan sekaligus peluang yang menghadang organisasi, dan mampu menggunakan Potensi secara harmonis untuk kemajuan organisasi. Sebagaimana yang diharapkan saat ini adalah pemimpin yang memiliki visi ke depan, yang diikuti dengan tindakan strategis yang tinggi, memiliki visioner.

Seorang pemimpin dalam suatu perusahaan mempunyai tanggung jawab terhadap kinerja pegawai, apabila karyawannya bekerja dengan baik dan penuh rasa tanggung jawab, maka kinerja yang dihasilkan akan berkualitas, dan tujuan perusahaan dapat dicapai sesuai dengan visi dan misi organisasi. Berarti Tugas seorang pemimpin dalam meningkatkan kinerja karyawan, yaitu dengan menjalankan strategi antara lain dengan memberikan motivasi dan menegakkan disiplin pada karyawan. Sesuai dengan apa yang disampaikan olehRivai (2004) bahwa semakin kuat motivasi kerja, kinerja pegawai akan semakin tinggi.

\section{DAFTAR RUJUKAN}

Adair, John. 2011. John Adair's 100 Greatest Ideas for Effective Leadership. West Sussex, UK: Capstone Publishing Ltd (A Wiley Company).

Alimuddin, 2002, Pengaruh Gaya Kepemimpinan terhadap Kinerja Pegawai Badan Pengawasan Daerah Kota Makassar, Tesis, Program Pasca Sarjana Magister Manajemen Universitas Gajah Mada (tidak dipublikasikan

Anoraga, Panji, 2001, Psikologi Kerja, Rineka Cipta, Yogyakarta

Arep, Ishak dan Hendri Tanjung. (2003). Manajemen Motivasi. Penerbit PT.Gramedia Widiasarana Indonesia, Jakarta.

Ari Retno Habsari, 2008, Terobosan Kepemimpinan, Med Press, Yogyakarta

A.M. Kadarman, dan Yusuf Udaya, 2001, Pengantar Ilmu Manajemen, PT. Prenhallindo.

Boediharjo.2002,Kinerja Erlangga, Jakarta.

Burton, James P; Lee, Thomas W; Holtom, Brooks C, 2002, The Influence of Motivation to Attend, Ability to Atend, and Organizational Commitment on Different Types of Absence Behaviours, Journal of Managerial Issues, Summer, 2002, p:181-197. 
Engkoswara, dan Aan K. (2011). Administrasi Pendidikan. Bandung: Alfabeta.

Fahmi, Irham. (2010). Manajemen Kinerja teori dan Aplikasi. Bandung: Alfabeta.

Hadari Nawawi. (2006). Evaluasi dan Manajemen Kinerja di Lingkungan Perusahaan dan Industri. Yogyakarta: UGM Press.

Hasibuan, Malayu. (2013). Manajemen Sumber Daya Manusia: Jakarta Bumi Aksara

Jacobs, E., Robert L. L. Masson, Riley L. Harvill, dan Christine J. Schimmel. 2012. Group Counseling: Strategies and Skills. Beltmont, CA: Cengage Learning.

Kreitner, Robert dan Angelo Kinick, 2003, Perilaku Organisasi, Salemba Empat, Jakarta

Luthans, Fred, 2006, Perilaku Organisasi, Edisi Sepuluh, Penerbit Andi, Yogyakarta.

Kreitner, Robert; dan Kinicki, Angelo, 2005,Perilaku Organisasi, Buku 1, Edisi Kelima, Salemba Empat, Jakarta.

Mangkunegara, A.P. (2005). Manajemen Sumber Daya Manusia. Bandung: PT. Remaja Rosdakarya.

Morgan, Howard, Phil Harkins, dan Marshal Goldsmith. 2006. The Art and Practice Leadership Coaching. Alih bahasa: Santi Indra Astuti. Jakarta: PT Transmedia.

Muenjohn, Nuttawuth dan Anona Armstrong. 2007. Transformational Leadership: The Influence of Culture on the Leadership Behaviours of Expatriate Managers. International Journal of Business and Information, Volume 2, Number 2, December 2007, pp.265283.

M.S. P. Hasibuan, 2007, Manajemen SDM, Edisi Revisi PT. Bumi Aksara, Jakarta.

Payamta, 2003, Gaya Kepemimpinan : Perkembangan dan Kepemimpinan Dalam Era Global, Telaah, September No. 13
Purwanto, Yadi, 2001. Makalah Manajemen Organisasi, Jakarta: PT. Cendekia Informatika

Rivai, Veithzal, 2004, Manajemen Sumber Daya Manusia Untuk Perusahaan, Rajawali Pers, Jakarta.

Robbins, Stephen.P. 2003. Organizational Behavior. Tenth Edition. New Jersey. By Person Education. Inc.

Ranupandojo, H, Suad Husnan. 2000. Manajemen Sumber Daya Manusia. Yogyakarta: BPFE-UGM.

Sedarmayanti. (2011). Membangun dan Mengembangkan Kepemimpinan serta Meningkatkan Kinerja untuk Meraih Keberhasilan. Bandung: Refika Aditama.

Siagian, Sondang P. 2006. Manajemen Sumber Daya Manusia. Jakarta: Penerbit Bumi Aksara.

Tett R. P., \& J. P Meyer, 1993, Job Satisfaction Organizational Commitment, Turnover Intention, and Turnover: Path Analyses Based on Meta-Analytic Findings, Personnel Psychology 46(2): 259-93.

Tisnawati e.sule, saefullah kurniawan,2010.Pengantar Manajaemen.Jakarta:Kencana

Umar, Husein. 2008. Business An Introduction. Jakarta: PT Gramedia Pustaka Utama.

Veitzhal Rivai. (2004). Kepemimpinan Dan Perilaku Organisasi. Jakarta: PT.Raja Grafindo.

Wahjosumidjo. (2002). Kepemimpinan Kepala Sekolah: Tinjauan Teoritik danPermasalahannya. Jakarta: Raja Grafindo Persada.

Wahjosumidjo. 1984. Kepemimpinan dan Motivasi. Jakarta: Ghalia Indonesia.

Wirawan. (2009). Evaluasi Kinerja Sumber Daya Manusia. Jakarta: Salemba Empat

Yukl, Gary. 2002. Kepemimpinan dalam Organisasi (Edisi Bahasa Indonesia). Prenhallindo. Jakarta. 